\title{
EDITORIAL
}

\section{Three years of Stem Cell Research \& Therapy}

Philippa Locke ${ }^{1 *}$, Timothy O'Brien ${ }^{2}$ and Rocky S Tuan ${ }^{3}$

\section{Editorial}

This year we celebrate three years of publication of Stem Cell Research $\mathcal{E}$ Therapy. In this short space of time, as the number of journals in the stem cell and regenerative medicine field has grown and continues to grow dramatically, Stem Cell Research \& Therapy has become established as the destination for high quality open access research into stem cell therapeutics.

\section{Why Stem Cell Research \& Therapy?}

When submitting work to a journal, authors understandably wish to be assured of the journal's quality. So what makes Stem Cell Research \& Therapy the leading forum for translational stem cell research?

\section{Scope, indexing, and impact}

Stem Cell Research E Therapy was launched in 2010 and was the first journal to focus on translational stem cell research [1]. We also publish basic and clinical research with a particular interest in the use of stem cells for drug discovery and testing, stem cell manufacture, and biomaterials. As discussed in last year's editorial [2], the journal was accepted for indexing in MEDLINE from volume 1 . The selection process for MEDLINE is similar to the National Institutes of Health's grant-making process; journals are reviewed by a committee, and scientific merit and quality of the editorial work are important considerations in this process [3], so authors can be sure their article will be easily searchable via PubMed, and that Stem Cell Research \& Therapy has been recognized as publishing content of suitable standard and value to the community. Similarly, Stem Cell Research \& Therapy was accepted for tracking early by Thomson Reuters and received its first partial Impact Factor (of 3.21), an important metric in the research community, in the 2011 Journal Citation Report.

\footnotetext{
* Correspondence: editorial@stemcellres.com

'BioMed Central, Floor 6, 236 Gray's Inn Road, London WC1X 8HB, UK

Full list of author information is available at the end of the article
}

\section{A responsible and respected publisher}

Since 2000, BioMed Central has been a pioneer of the open access publishing model. A member of the Committee on Publication Ethics (COPE), BioMed Central regularly reviews its editorial policies and processes to ensure that they meet the highest standards [4]. All of the research published in Stem Cell Research \& Therapy is thoroughly peer-reviewed and deposited in a number of open access archives to ensure its continual availability [5].

\section{Our international, multidisciplinary Editorial Board}

As well as assisting in the review of manuscripts, the Stem Cell Research \& Therapy Editorial Board offers invaluable guidance on the journal's commissioned content and development. The Editorial Board members reflect the diversity in the field, from basic scientists to clinicians, including surgeons [6]. We aim to ensure that the board reflects the international nature of the journal and regularly review the contributions of its members to ensure that the board remains engaged and active.

\section{What are we publishing?}

In 2012, we published 23 research articles, 23 reviews, 9 commentaries, and 2 editorials. By the end of March 2013, we had already published 18 research articles, 8 reviews, and 5 commentaries - submissions are also increasing, so we expect that our publication numbers will continue to rise.

\section{Our authors}

Of the 23 research publications in 2012, 2 were from Africa, 5 from Asia, 8 from Europe, and 8 from North America. We are always looking for opportunities to promote the journal to an international audience and to ensure that cost is never a barrier to publishing with us.

\section{Who's reading what}

We are seeing strong increases in the number of article accesses; average monthly accesses exceeded 40,000 in the first quarter of 2013. The majority of visitors to the website are from the US, followed by China, the UK, and India, then Japan, Germany, Canada, Italy, and Australia. 
Our most-accessed articles published in 2012 were from: Magali Cucchiarini and colleagues [7], who enhanced the chondrogenic capacity of human mesenchymal stem cells by SOX9 gene transfer; Nesrine Ben Azouna and colleagues [8], who replaced fetal bovine serum with human platelet lysate for the culture of mesenchymal stem cells; and Adetola Adesida and colleagues [9], who demonstrated that isolating and expanding bone marrow mesenchymal stromal cells in hypoxic conditions increases their chondrogenic potential.

The most-read reviews of the year were from Wesley Jackson and colleagues [10], who used mesenchymal stem cells to reduce scarring in wound healing, and Anish Majumdar and colleagues [11], who reviewed the therapeutic potential of bone marrow stromal cells for cartilage repair in osteoarthritis. The review by Majumdar and colleagues was published as part of the thematic series on 'Clinical applications of stem cells', edited by Mahendra Rao, whose launch editorial on stem cells and regenerative medicine was also popular [12].

\section{What's next?}

This year will see the publication of the final articles in the 'Clinical applications of stem cells' series [13] and 'Physical influences on stem cells' edited by Gordana VunjakNovakovic [14]. The series on 'Stem cell research in the Asia-Pacific', edited by Oscar Lee, Songtao Shi, Yufang Shi, and Ying Jin, showcasing a selection of the innovative research from this region [15], will also be completed.

Ronald $\mathrm{Li}$, of the University of Hong Kong, will edit our first thematic series for 2013, focusing on cardiovascular regeneration. Further exciting series will soon be announced, and research submissions are welcomed for consideration alongside the commissioned review and opinion pieces. We will also continue to publish individual reviews on topics of importance to the field, such as upcoming articles from Luc Sensebé on producing mesenchymal stem cells according to Good Manufacturing Practices and from Karin Tarte on the immunoregulatory properties of these cells.

We will continue to promote the quality content that the journal publishes on its website, BioMed Central's Stem Cell gateway, and through blog posts and press releases. The launch of the BioMed Central magazine, Biome [16], also offers us a new venue to ensure that our articles are brought to the attention of as wide an audience as possible. As submissions increase, we will be taking necessary steps to ensure that our authors continue to benefit from our fair, fast, and thorough peer-review process and expeditious publication. Our aim is for all of our authors to continue to publish with us in the future, like Bruce Bunnell, who has published three research articles [17-19] in Stem Cell Research \& Therapy so far!

\section{What can we do for you?}

We are very interested in hearing the views of the research community we serve. Do you have any feedback on your experience with the journal? Is there a topic you would like to read about, an author you would like to see featured, or a new article type you think we should publish in Stem Cell Research \& Therapy? Perhaps you have a suggestion for a feature you would like to see on the website or a way of making articles easier to read or access. You are welcome to send comments and suggestions via the editorial office or visit the BioMed Central stand at one of the many conferences we exhibit at throughout the year [20].

\section{Competing interests}

$\mathrm{PL}$ is an employee of BioMed Central and receives a fixed salary. TO and RST are the Editors-in-Chief of Stem Cell Research \& Therapy and receive an annual honorarium. TO is founder, director, and equity holder of Orbsen Therapeutics (Galway, Ireland).

\section{Author details}

'BioMed Central, Floor 6, 236 Gray's Inn Road, London WC1X 8HB, UK. ${ }^{2}$ REMEDI - National Centre for Biomedical Engineering Science, National University of Ireland, Galway, Ireland. ${ }^{3}$ Center for Cellular and Molecular Engineering, University of Pittsburgh School of Medicine, 450 Technology Drive, Room 221, Pittsburgh, PA 15219-3143, USA.

\section{Published: 1 May 2013}

\section{References}

1. Donnelly A, Johar S, O'Brien T, Tuan RS: Welcome to Stem Cell Research \& Therapy. Stem Cell Res Ther 2010, 1:1.

2. Locke P, Tuan RS, O'Brien T: Stem Cell Research \& Therapy in 2012. Stem Cell Res Ther 2012, 3:16.

3. MEDLINE ${ }^{\oplus}$ Journal Selection Fact Sheet [http://www.nlm.nih.gov/pubs/ factsheets/jsel.html]

4. BioMed Central Editorial Policies [http://www.biomedcentral.com/about/ editorialpolicies]

5. Permanency - BioMed Central [http://www.biomedcentral.com/about permanency]

6. Stem Cell Research \& Therapy Editorial Board [http://stemcellres.com/about/ edboard]

7. Venkatesan JK, Ekici M, Madry H, Schmitt G, Kohn D, Cucchiarini M: SOX9 gene transfer via safe, stable, replication-defective recombinant adenoassociated virus vectors as a novel, powerful tool to enhance the chondrogenic potential of human mesenchymal stem cells. Stem Cell Res Ther 2012, 3:22.

8. Ben Azouna N, Jenhani F, Regaya Z, Berraeis L, Ben Othman T, Ducroca E, Domenech J: Phenotypical and functional characteristics of mesenchymal stem cells from bone marrow: comparison of culture using different media supplemented with human platelet lysate or fetal bovine serum. Stem Cell Res Ther 2012, 3:6.

9. Adesida $A B$, Mulet-Sierra A, Jomha NM: Hypoxia mediated isolation and expansion enhances the chondrogenic capacity of bone marrow mesenchymal stromal cells. Stem Cell Res Ther 2012, 3:9.

10. Jackson WM, Nesti LJ, Tuan RS: Mesenchymal stem cell therapy for attenuation of scar formation during wound healing. Stem Cell Res Ther 2012, 3:20.

11. Gupta PK, Das AK, Chullikana A, Majumdar AS: Mesenchymal stem cells for cartilage repair in osteoarthritis. Stem Cell Res Ther 2012, 3:25

12. Rao M: Stem cells and regenerative medicine. Stem Cell Res Ther 2012 , $3: 27$.

13. Clinical applications of stem cells [http://stemcellres.com/series/clinical]

14. Physical influences on stem cells [http://stemcellres.com/series/physical]

15. Stem cell research in the Asia-Pacific [http://stemcellres.com/series/asiapacific]

16. Biome [http://www.biomedcentral.com/biome] 
17. Danchuk S, Ylostalo JH, Hossain F, Sorge R, Ramsey A, Bonvillain RW, Lasky JA, Bunnell BA, Welsh DA, Prockop DJ, Sullivan DE: Human multipotent stromal cells attenuate lipopolysaccharide-induced acute lung injury in mice via secretion of tumor necrosis factor-a-induced protein 6 . Stem Cell Res Ther 2011, 2:27.

18. Pandey AC, Semon JA, Kaushal D, O'Sullivan RP, Glowacki J, Gimble JM, Bunnell BA: MicroRNA profiling reveals age-dependent differential expression of nuclear factor $\mathrm{KB}$ and mitogen-activated protein kinase in adipose and bone marrow-derived human mesenchymal stem cells. Stem Cell Res Ther 2011, 2:49.

19. Zhang S, Danchuk SD, Imhof KM, Semon JA, Scruggs BA, Bonvillain RW, Strong AL, Gimble JM, Betancourt AM, Sullivan DE, Bunnell BA: Comparison of the therapeutic effects of human and mouse adipose-derived stem cells in a murine model of lipopolysaccharide-induced acute lung injury. Stem Cell Res Ther 2013, 4:3.

20. Visit Us - BioMed Central [http://www.biomedcentral.com/events/visitus]

doi:10.1186/scrt196

Cite this article as: Locke et al: Three years of Stem Cell Research \&

Therapy. Stem Cell Research \& Therapy 2013 4:46. 